\title{
Numerical Experiments of the Land and Sea Breeze Circulation
}

\author{
by \\ Naosuke Saito \\ Meteorological Research Institute, Tokyo
}

(Received July 22, 1976)

\begin{abstract}
An effect of the urban heat island on modification of the land and sea breeze circulation was discussed by making a differential diurnal temperature change between urban and suburban areas. Here a two dimensional numerical model was applied, and the following assumption was used: higher daily mean temperature and smaller diurnal change in urban area and colder mean temperature and larger diurnal change in suburban area. Under these conditions invasion of sea breeze was slowed down and land breeze was intensified. Double vertical circulation cells were formed; one was around the coastline and another along the border between the urban and suburban areas.

A three-dimensional experiment of the land and sea breeze circulation over the Kanto district of Japan was integrated in a domain of $204 \mathrm{~km} \times 204 \mathrm{~km} \times 1.8 \mathrm{~km}$ for two simulated days. In this experiment the actual coastline was outlined in the grid of $6 \mathrm{~km}$ meshpoint interval, and a uniform diurnal temperature change was assumed on the land area. The computed land breeze and sea breeze were converged or diverged according to a concave or convex coastline. Internal gravity oscillations were found in the front of sea breeze.
\end{abstract}

\section{Introduction}

The purpose of this experiment is a simulation of a local wind circulation which is directly affected by air-temperature variations near the surface of the earth. Short wave radiation from the sun is supposed to be uniform so long as we are concerned with a local phenomenon. However, heating of the earth is variable according to many uneven physical conditions of the earth surface-topography, buildings, natural covering conditions on the ground etc. The variations in air temperature near the surface yield perturbations of pressure in the lower atmosphere. The latter can give rise to a motion of air. The best example of this idealized air flow is the land and sea breeze circulation. The non-linear equation of the sea breeze circulation has been studied by many authors, e.g., EsToQUE (1961, 1962, 1969), Magata (1965), and NeUmanN and
MAHRER (1971). ESTOQUE's attractive work discussed many aspects of land and sea breeze. His model consisted of a constant flux sublayer close to the surface and a transition sublayer. Furthermore the eddy conductivity were made functions of the Richardson number. MAGATA's stimulating work introduced heat exchange between ground and atmosphere into the problem of land and sea breeze: in his paper, the thermal boundary condition at the surface was prescribed-flux condition. NEUMANN and MAHERE modified the Estoque model. In particular the equation of continuity was retained in its original form. Recently PIELKE (1974) treated a three-dimensional numerical model of the sea breeze over South Florida.

The present author's primary concern is local circulation induced by an uneven distribution of surface temperatures. Therefore, a prescribed temperature condition is 
adopted as the boundary condition, but the idea of boundary layer is not introduced. This text is divided into two parts. In the first part a result of numerical simulating of "the urban heat island" effect on a pure two-dimensional land and sea breeze circulation is presented. Here a differential diurnal temperature change between urban and subruban areas was assumed. In the second part a numerical experiment of the threedimensional land and sea breeze circulation is presented. The aim of the experiment was a simulation of the land and sea breeze in the Kanto district of the Japanese Main Island. Therefore the actual coastline was introduced in the experiment.

\section{A two-dimensional model}

\subsection{Basic frame of model}

The land and sea breeze in two dimensions has been discussed by many authors mentioned in Section 1. The present experiment, however, adopts a slightly different model and boundary conditions from thoes of previous works. An atmosphere where perturbations are limited under a height of $1.8 \mathrm{~km}$ is the frame for our local circulation experiment. In this atmosphere meteorological fields are assumed to be the sum of large-scale or undisturbed values plus mesoscale variations or perturbations. The latter are induced by a diurnal temperature variation at the surface. Here the large-scale field is chosen as steady and at rest. The potential temperature of the large-scale field is uniform in horizontal plane and has a stable vertical profile.

Let us define the Exner function $\pi^{*}$ for the whole field including the large-scale and meso-scale fields as follows:

$$
\pi^{*}=J C_{p} \bar{\theta}\left(\frac{p}{1000}\right)^{A R / C_{p}}
$$

where $p$ is the pressure, $J=1 / A$ is the mechanical equivalent of heat, $R$ is the gas constant and $C_{p}$ is the specific heat of air at constant pressure, and $\bar{\theta}$ is the potential temperature of an appropriate constant value. In our experiments we choose $\bar{\theta}$ as the average value for the large-scale potential temperature field.

Differentiating $\pi^{*}$ with respect to height $z$, we have the following relation:

$$
\frac{\partial \pi^{*}}{\partial z}=-g \frac{\bar{\theta}}{\theta^{*}},
$$

where

$$
\theta^{*}=T\left(\frac{1000}{p}\right)^{A R / C_{p}}
$$

Let $I I$ and $\Theta$ denote the Exner function and the potential temperature in the steady field respectively, and let $\pi$ and $\theta$ designate local perturbations of the two parameters. Then we may write

$$
\pi^{*}=\Pi+\pi \text { and } \theta^{*}=\Theta+\theta .
$$

From the relation (1) and using the approximation $\Theta \gg \theta$, the hydrostatic relations for the steady field and the meso-scale field may be written as follows:

$$
\frac{\partial \Pi}{\partial z}=-g-\frac{\bar{\theta}}{\Theta}
$$

and

$$
\frac{\partial \pi}{\partial z}=g \frac{\theta \bar{\theta}}{\Theta^{2}} \fallingdotseq g \frac{\theta}{\bar{\theta}} .
$$

Here as mentioned earlier, $\Theta$ is a function of height only. The difference $\bar{\theta}-\Theta$, however, is the order of one per cent, and we may assume $\Theta \fallingdotseq \bar{\theta}$. Therefore, in the last term of (3) $\bar{\theta}$ is used as a denominator. Because the constant denominator in (3) yields a simpler energy equation. The horizontal pressure gradient in the meso-scale field is expressed by $(-\Theta / \vec{\theta}) \nabla \pi$. This expression takes a simpler form $-\nabla \pi$ by using the same approximation $\Theta \fallingdotseq \bar{\theta}$.

We choose a Cartesian co-ordinate system. This co-ordinate system is placed on the surface of the earth. The $z$-axis points upward, and the $x$-axis is perpendicular to a coastline, and the $y$-axis is along the coastline. Here the coastline is a straight line and temperature field is uniform in the $y$ direction. The equation governing the mesoscale variations may be written as follows:

$$
\frac{\partial u}{\partial t}+u \frac{\partial u}{\partial x}+w \frac{\partial u}{\partial z}=-\frac{\partial \pi}{\partial x}+\frac{\partial}{\partial z}\left(K^{-} \frac{\partial u}{\partial z}\right)
$$




$$
\begin{aligned}
& \frac{\partial \pi}{\partial z}=g \theta / \bar{\theta} \\
& \frac{\partial \theta}{\partial t}+u \frac{\partial \theta}{\partial x}+w \cdot \frac{\partial \theta}{\partial z}=-S w+\frac{\partial}{\partial z}\left(K \frac{\partial \theta}{\partial z}\right) \\
& -\frac{\partial u}{\partial x}+\frac{\partial w}{\partial z}=0
\end{aligned}
$$

Here $u$ and $w$ represent the velocity components along $x_{-}$and $z$-axes, $\theta$ is the perturbation of potential temperature, $K$ is the eddy diffusivity, and $S \equiv \partial \Theta / \partial z$ : a stability representing a vertical profile of $\Theta$. Only $S$ is dependent on the property of the large-scale field.

In the system of equations, incompressibility of the air is assumed. Since we are considering a shallow atmosphere this assumption may be adequate as argued by PielKe (1974).

\subsection{Conditions for numerical integration}

The air in this model is at rest at the surface $(z=0)$. The temperature at the surface is dependent on the heat balance at the interface between air and ground. Therefore it should be described by a function built in the model. However, from the primary purpose and for the sake of simplicity, a prescribed condition is adopted;

and

$$
z=0: u=w=0
$$

$$
\theta=A(x) \sin \left(\frac{2 \pi}{T^{-}} t\right)+\theta_{0}(x),
$$

where $T=24 \mathrm{hr}$.

The variation in the air temperature at the lower boundary propagates upward, but the amplitude of the variation decreases with height as the well-known theory of eddy heat conduction shows. The upper boundary of our model is taken at a height where the amplitude of air temperature variation takes a small value that can be neglected. When the value of $K$ is of the order of $1 \mathrm{~m}^{2} / \mathrm{sec}$, the amplitude of air temperature wave becomes almost negligible at a height of $1.5 \mathrm{~km}$ so long as the temperature change is caused by the eddy diffusion. In this experiment the following profile of
$K$ was used: $K$ linearly increases with height in the lowest $300 \mathrm{~m}$ layer and has a constant value above $300 \mathrm{~m}$,

$$
\begin{aligned}
& K=\left(\frac{z}{300}\right) K_{0} \text { for } 300 \mathrm{~m} \geqq z \geqq 0 \\
& K=K_{0} \text { for } z>300 \mathrm{~m}
\end{aligned}
$$

where $K_{0}=1 \mathrm{~m}^{2} / \mathrm{sec}$. The value of $K$ and its profile are due to MAGATA's paper (MAGATA 1956).

The upper boundary was put at a height of $1.8 \mathrm{~km}$, and the following boundary conditions are used:

$$
\frac{\partial u}{\partial z}=\frac{\partial \theta}{\partial z}
$$

and

$$
w=0
$$

As the equation (7) is the first order differential equation, the second condition (11) is needless. This rigid wall boundary condition, however, was adopted in order to eliminate a trouble which was expected from the external gravity wave. In our experiments, this kinematic condition allowed a forced current to appear near the upper boundary. The forced current was not so strong that the main part of our results was spoiled. In the three-dimensional experiment, the upper rigid boundary was abolished, and the computation domain was connected into the thermally neutral atmosphere, the autobarotropic atmospher. The horizontal gradients of $u$ and $\theta$ at lateral boundaries were set to be zero.

The initial conditions are

and

$$
u=w=0
$$

$$
\theta=\theta_{0}(x)
$$

The stable thermal stratification in the undisturbed field was set in such a manner that the value of stability is constant in the lower layer and gradually approaches to a neutral state above a height of $800 \mathrm{~m}$;

$$
\begin{aligned}
& S=S_{0}: z \leqq 800 \mathrm{~m} \\
& S=S_{0} \times 0.6^{2},
\end{aligned}
$$

where

$$
\lambda \equiv(z-800) / 200: z>800 \mathrm{~m} .
$$




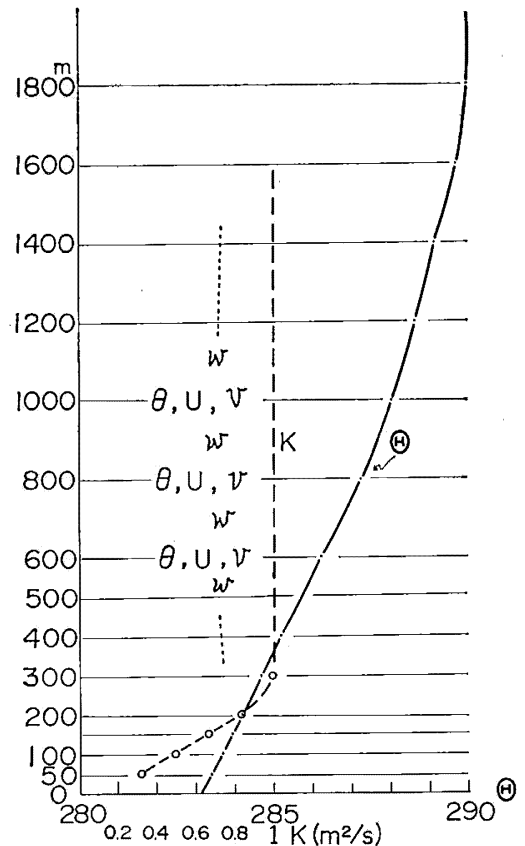

Fig. 1. Vertical spacing and arrangement of dependent variables in the model. The thick line is the vertical profile of potential temperature in the basic field, and the broken line is the profile of the vertical eddy exchange coefficient used in the model.

This vertical profile of the potential temperature in the large-scale field is presented in Fig. 1. Our horizontal grid interval is $6 \mathrm{~km}$, and the vertical interval is $50 \mathrm{~m}$ between the surface and the $200 \mathrm{~m}$ level, and $100 \mathrm{~m}$ between the $200 \mathrm{~m}$ and $600 \mathrm{~m}$ levels, and $200 \mathrm{~m}$ from the $600 \mathrm{~m}$ to $1800 \mathrm{~m}$ levels. Fig. 1 shows the locations of the levels, the vertical profiles of $\Theta$ and $K$ and the arrangement of the dependent variables. The horizontal size of our computation domain is $204 \mathrm{~km}$. The finite difference schemes are the upstream scheme for a spatial difference and the Euler backward scheme (Matsuno scheme) for a time difference. The time step was six minutes.

\section{Results of the two-dimensional experiment}

By using the two-dimensional model two cases were experimented. Case (a) was one of the simplest land and sea breeze circulations where the temperatures on the land surface uniformly changed with time and the ones on the water surface were steady and uniform. The amplitude of diurnal temperature change on the land surface was $2^{\circ} \mathrm{K}$;

$$
\begin{array}{ll}
\theta=2^{\circ} \sin \left(-\frac{2 \pi}{T}-t\right): & \text { over land } \\
\theta=0^{\circ} \quad: \text { over water }
\end{array}
$$

Case (b) was an example of circulation under uneven temperature change at the land surface. In general, the thermal properties of a city area may be characterized by higher mean temperature and smaller diurnal variation (MAGATA 1972). Therefore when a city develops along a coastline the simple land and sea breeze circulation in Case (a) will be deformed. For example the morning air temperature is often lower in a suburban area and over water than in an urban area, then country air and sea air in the lowest layer drift into the center of the city. In Case (b) the area which is 18 kilometers away from the coastline was defined as an urban area, and the lower boundary condition of perturbed temperature was specified as follows:

$\theta=0^{\circ}$

$\theta=2.0^{\circ} \sin \left(\frac{2 \pi}{T}-t\right):$ on urban area

$\theta=-0.7^{\circ}+2.7^{\circ} \sin \left(\frac{2 \pi}{T} t\right)$ : on subruban area

Fig. 2(a) to Fig. 9(b) show the distributions of computed winds, temperatures and vertical motions for selected hours after simulated sunrise. In the illustrations of air flows the short lines with arrow-heads represent wind-directions composed with $u$ and $w$-components, and the full and broken lines are isotaches labelled in $\mathrm{cm} / \mathrm{sec}$. In the figures of vertical motions and of temperature perturbations, the thick and thin lines are isopleths of vertical speed labelled in $\mathrm{cm} / \mathrm{sec}$ and isotherms labelled in ${ }^{\circ} \mathrm{K}$ respectively.

After $3 \mathrm{hr}$, the sea breeze appeared in 


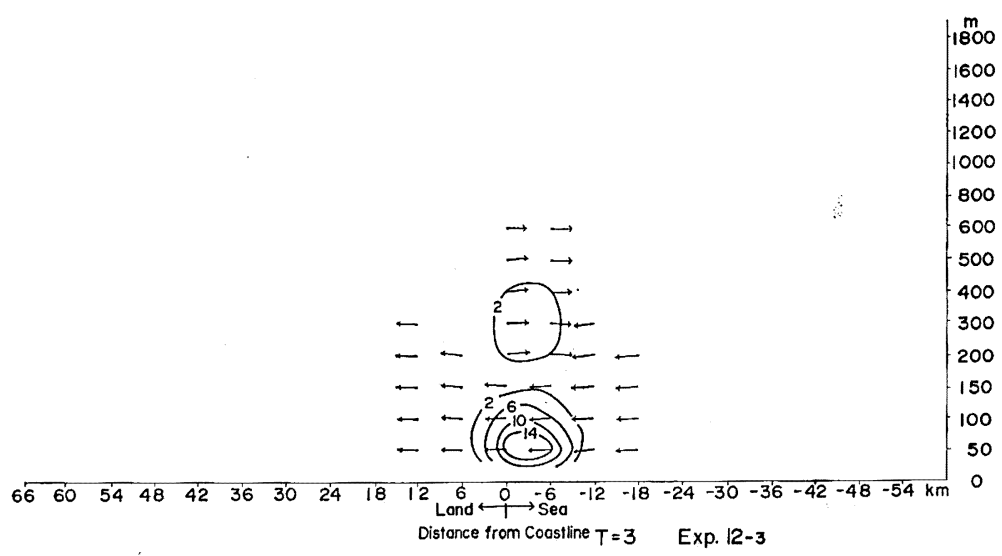

Fig. 2(a). Resultant wind directions (arrows) and isotaches (cm/sec full and dashed lines) in Case (a) at 3 hour after simulated sunrise.

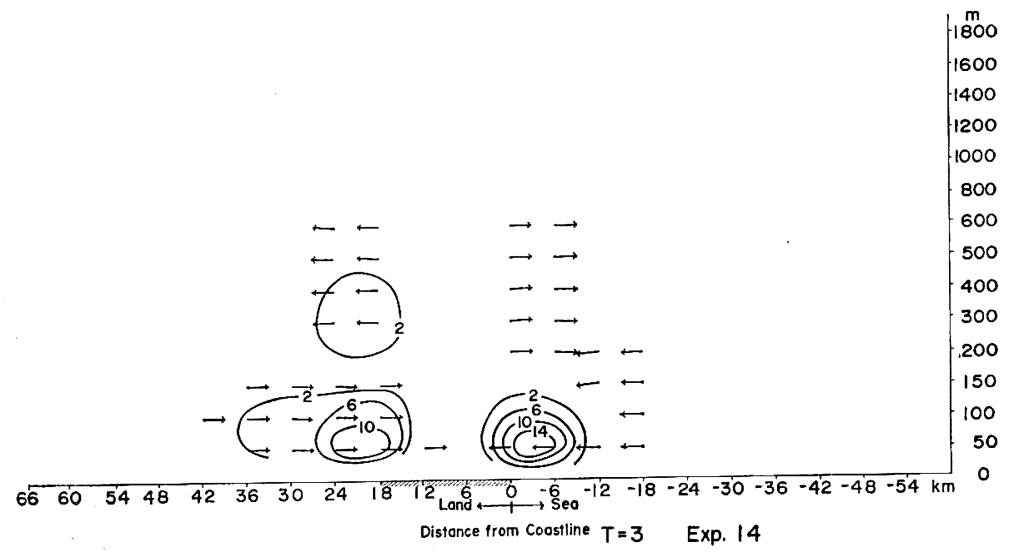

Fig. 2(b). Resultant wind directions (arrows) and isotaches (cm/sec, full lines) in Case (b) at 3 hour after simulated sunrise. The hatched shading under abscissa indicates the extension of urban area.

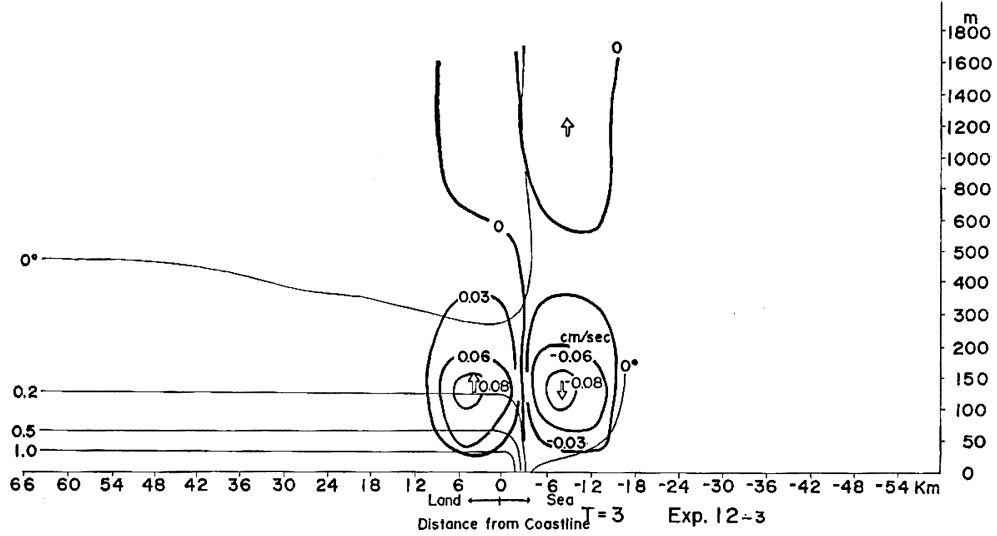

Fig. 3(a). Vertical motions (cm/sec, thick lines) and perturbed potential temperature $\left({ }^{\circ} \mathrm{K}\right.$, thin lines) in Case (a) at 3 hour after simulated sunrise. 


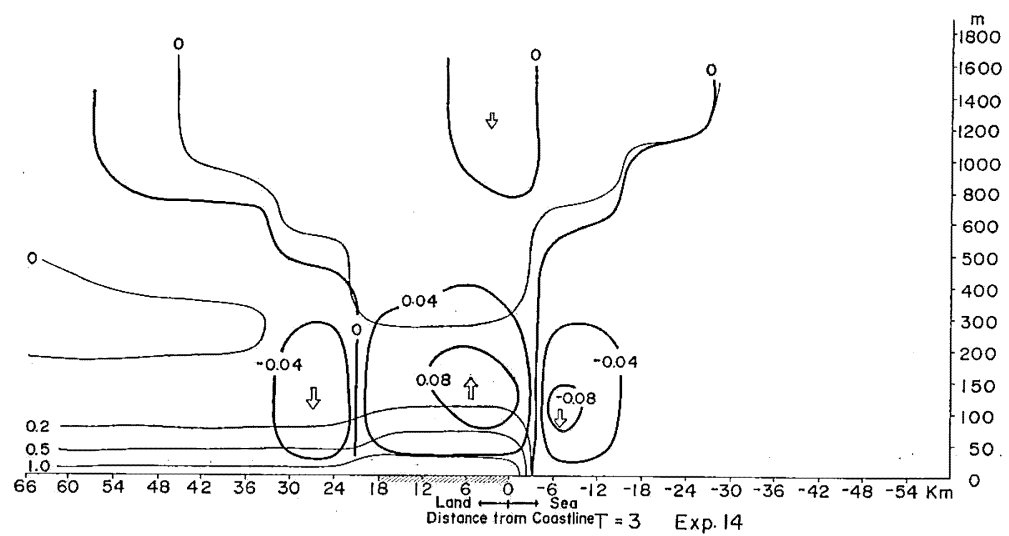

Fig. 3(b). Verfical motions (cm/sec, thick lines) and perturbed potential temperature $\left({ }^{\circ} \mathrm{K}\right.$, thin lines) in Case (b) at 3 hour after simulated sunrise.

the lowest $150 \mathrm{~m}$ layer near the shoreline and the counter-sea breeze was formed above the sea breeze. In Case (b) the suburban air started drifting into the urban area and converged with the sea breeze. The distributions of vertical motions show a single circulation cell in Case (a) and double circulation cells in Case (b) (Figs. $3(\mathrm{a})$ and 3(b)). After $9 \mathrm{hr}$ the sea breeze invaded the land area, and its depth became about twice that at $3 \mathrm{hr}$. In Case (b) the temperature in the suburban area again became lower than that in the urban. Therefore the air near the border flowed toward the urban area, and a new convergence zone was formed in the sea breeze over the inland area. From the patterns of isotaches it is found that the invasion of isotaches of $10 \mathrm{~cm} / \mathrm{sec}$ and $20 \mathrm{~cm} / \mathrm{sec}$ in Case (b) was much reduced in the lowest layer compared with the extension of isotaches of the same speeds in Case (a).

At $15 \mathrm{hr}$ the temperature on the land was colder than that on the sea, but the sea breeze still continued. The intensity of the sea breeze, however, apparently decreased, especially at the shoreline where the maximum counter-sea breeze pressure gradient was formed. In Case (b) the countersea breeze pressure gradient on the border of urban area retarded the air speed to almost a quarter of the inland air speed in Case (a). Such fine spatial variations in wind speeds are recognizable more clearly

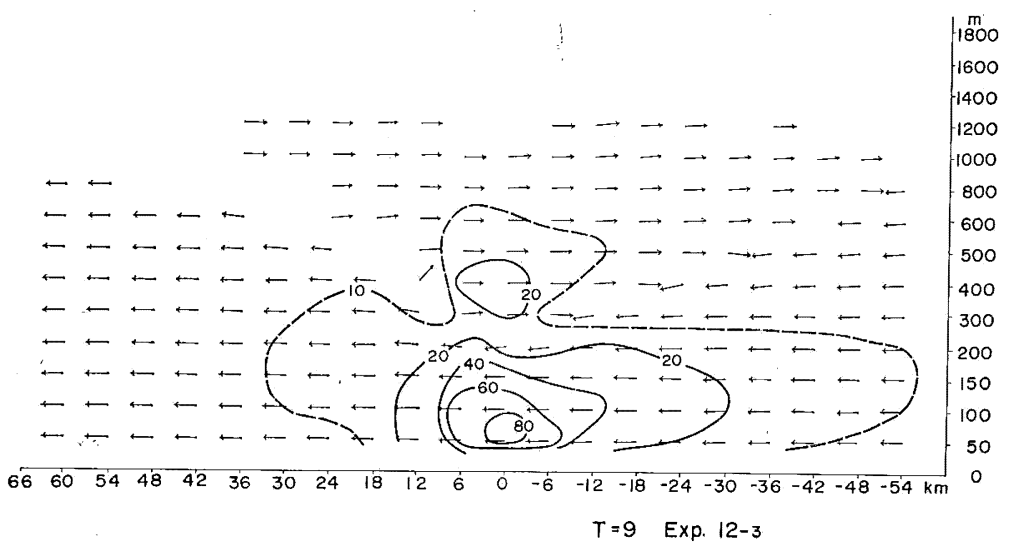

Fig. 4(a). Same as Fig. 2(a) except at 9 hour. 


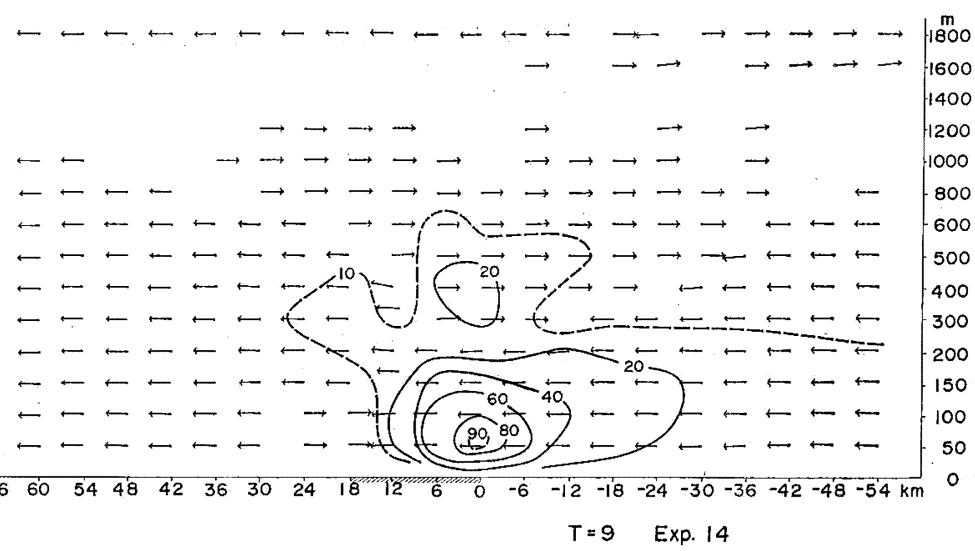

Fig. 4(b). Same as Fig. 2(b) except at 9 hour.

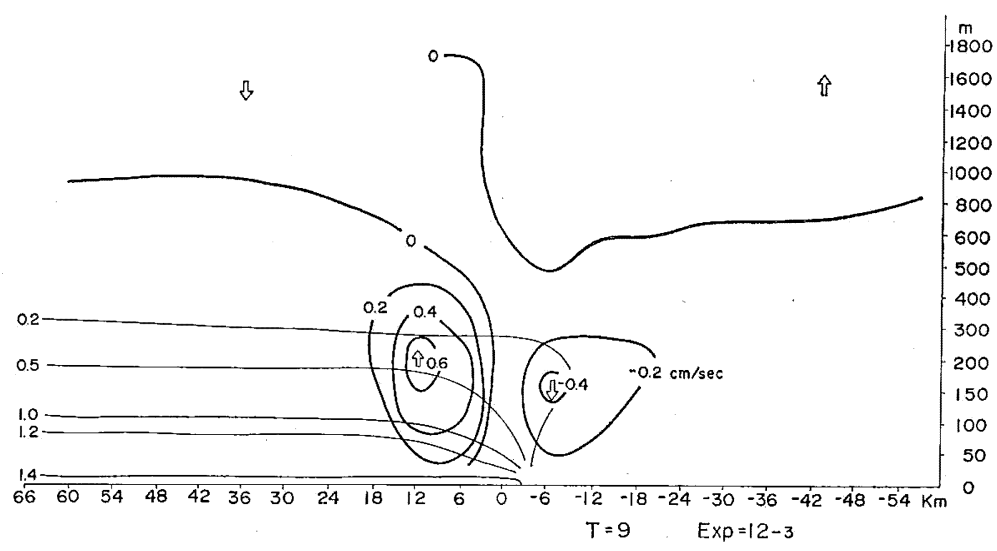

Fig. 5(a). Same as Fig. 3(a) except at 9 hour.

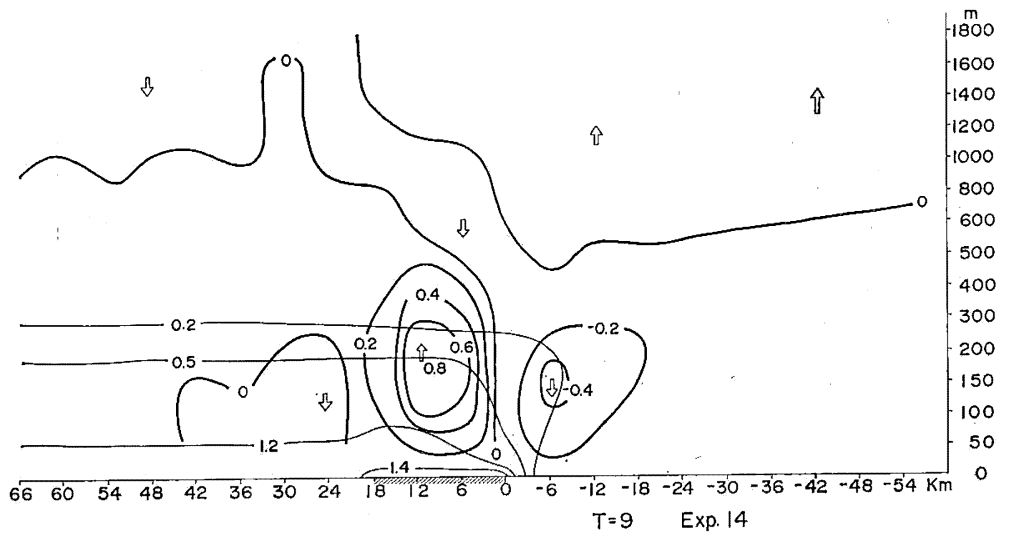

Fig. 5(b). Same as Fig. 3(b) except at 9 hour. 


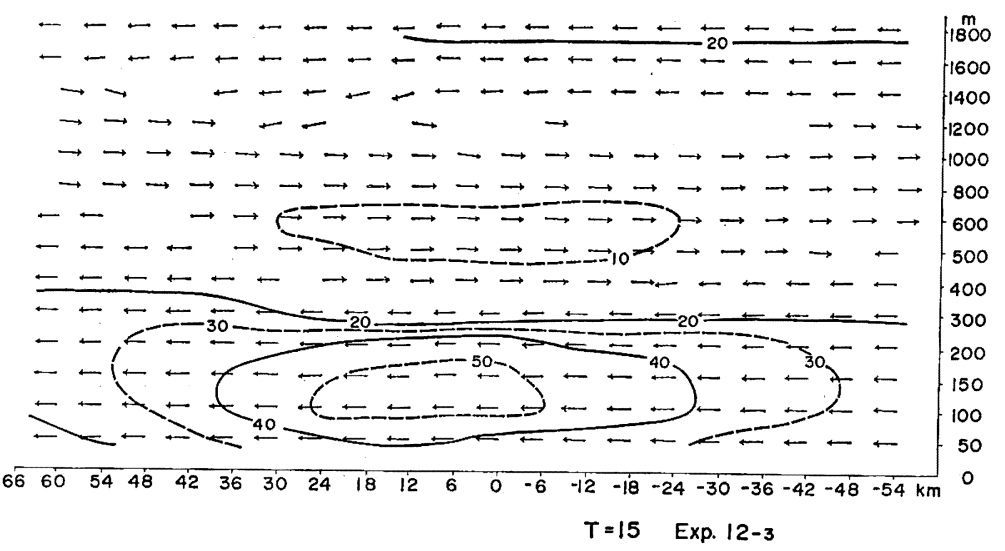

Fig. 6(a). Same as Fig. 2(a) except at 15 hour.

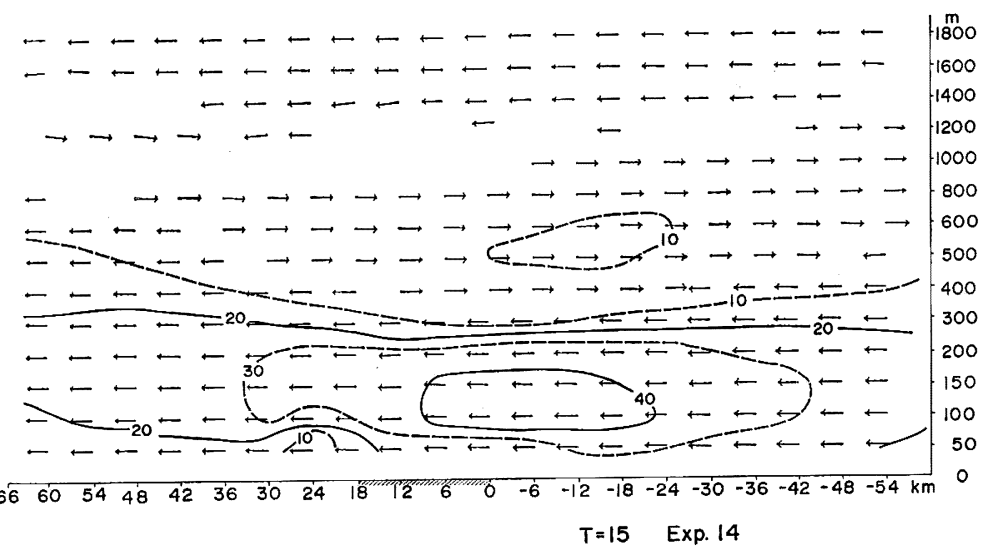

Fig. 6(b). Same as Fig. 2(b) except at 15 hour.

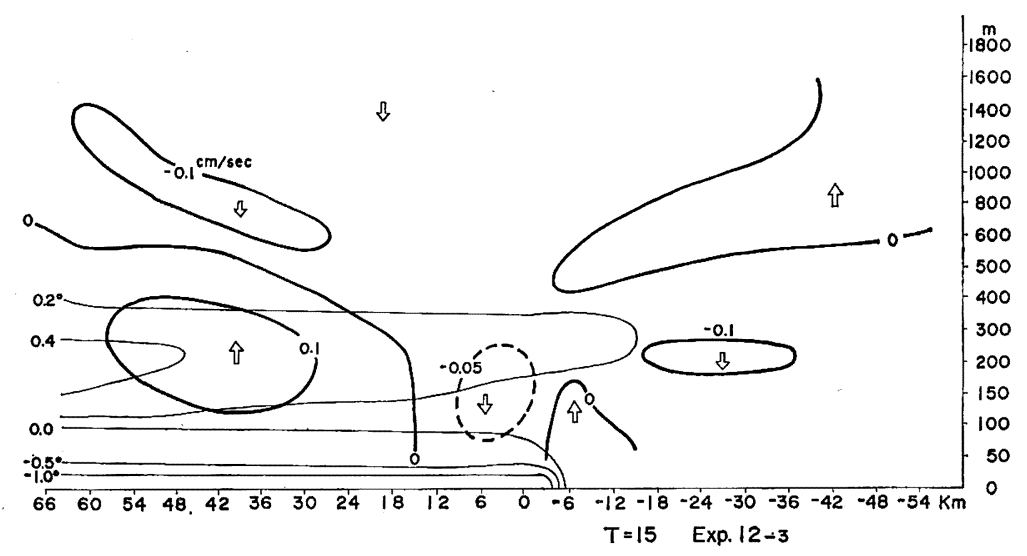

Fig. 7(a). Same as Fig. 3(a) except at 15 hour. 




Fig. 7(b). Same as Fig. 3(b) except at 15 hour.

in the patterns of vertical motions shown in Figs. 7(a) and 7(b). The figures reveal circulations having an opposite sense to the day time circulation; the offshore upward motion and, hence, horizontal convergence and the downward motion and, hence, horizontal divergence on the coastal area. We see another downward motion cell on the suburban area in Case (b).

At $21 \mathrm{hr}$ the land breeze developed on the coastal area. The counter-sea breeze in the day-time changed into flows toward the land above $200 \mathrm{~m}$ (Fig. 8(a)). The center of downward motion was formed over the coast and the center of upward motion was over the sea $12 \mathrm{~km}$ from the shoreline. In
Case (b) the lower temperature was given in the suburban area. Therefore, the land breeze became stronger, wider and deeper than the one in Case (a). Besides the simple pattern of land breeze in Case (a) was deformed into the double maxima type land breeze as shown in Fig. 8(b). One maximum was formed on the coastline and another on the border between urban and suburban areas. Connected with the offshore breeze and with the air-flow from country to city, the double circulation cells in the vertical motion field were clearly organized as shown in Fig. 9(b). Consequently a divergence area was formed at a height of about $200 \mathrm{~m}$ in the urban area.

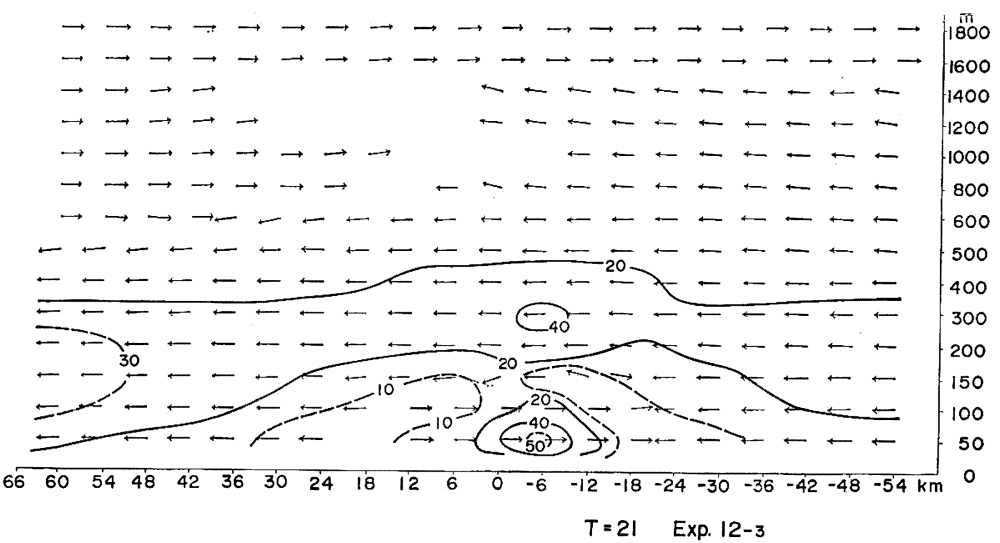

Fig. 8(a). Same as Fig. 2(a) except at 21 hour. 


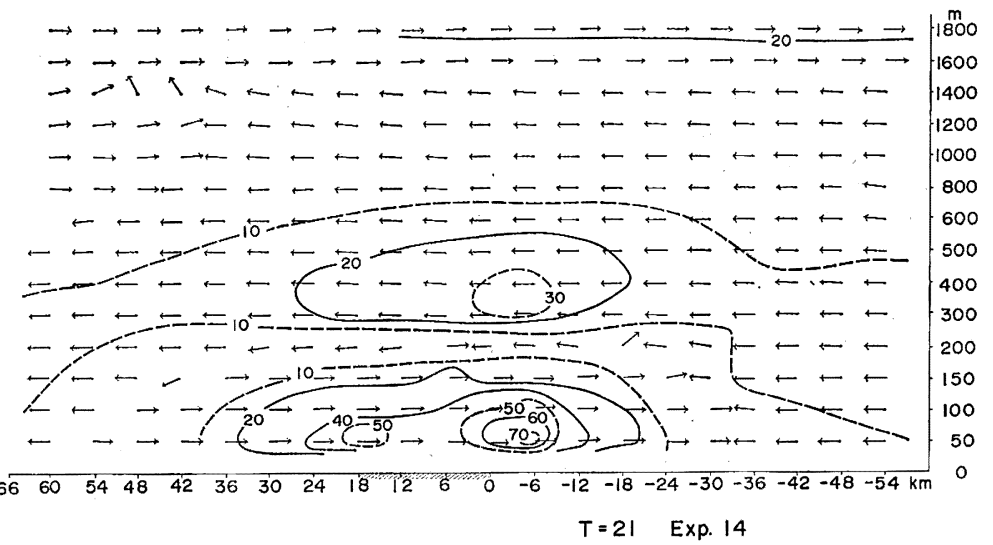

Fig. 8(b). Same as Fig. 2(b) except at 21 hour.

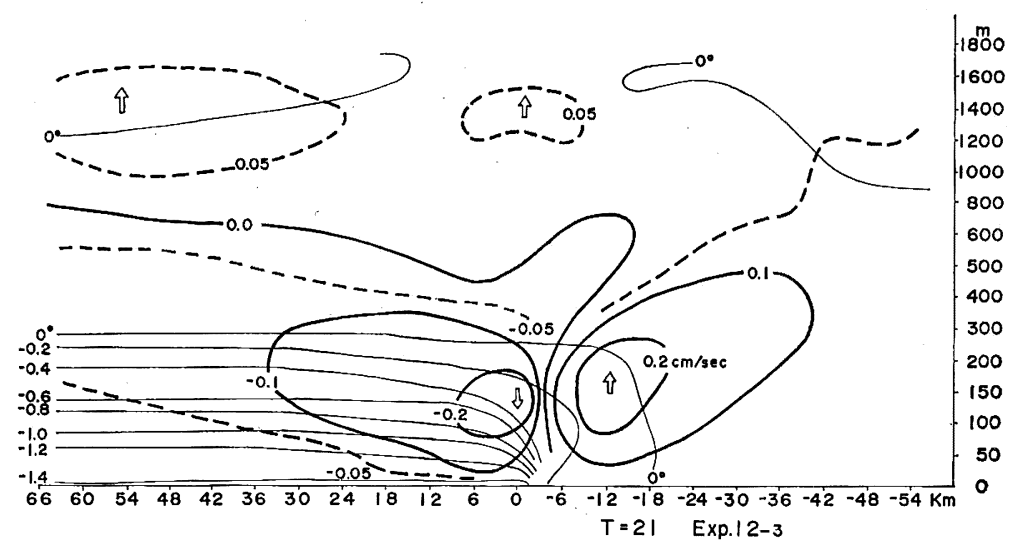

Fig. 9(a). Same as Fig. 3(a) except at 21 hour.

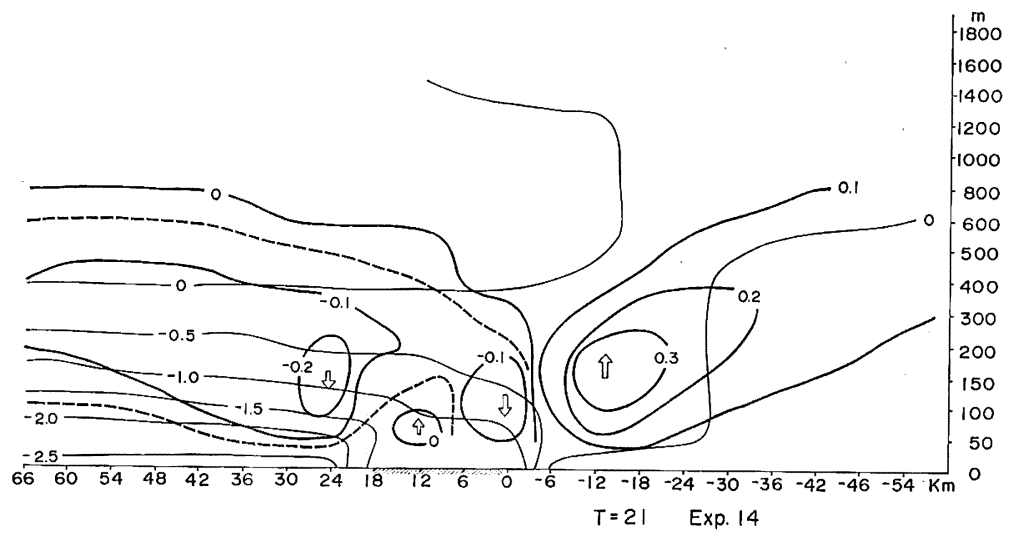

Fig. 9(b). Same as Fig. 3(b) except at 21 hour. 


\section{A three-dimensional model}

The two-dimensional model was expanded into a three-dimensional one. The Coriolis force and the horizontal eddy diffusion were introduced but the basic assumptions and the large-scale parameters were the same as those in the two-dimensional experiment.

\subsection{Model equations}

The equations for meso-scale variations may be written as follows :

$$
\begin{aligned}
& \frac{d u}{d t}=f v-\frac{\partial \pi}{\partial x}+K_{H}\left(-\frac{\partial^{2} u}{\partial x^{2}}+-\frac{\partial^{2} u}{\partial y^{2}}\right)+-\frac{\partial}{\partial z}\left(K-\frac{\partial u}{\partial z}\right) \\
& \frac{d v}{d t}=-f u-\frac{\partial \pi}{\partial y}+K_{H}\left(\frac{\partial^{2} v}{\partial x^{2}}+\frac{\partial^{2} v}{\partial y^{2}}\right)+-\frac{\partial}{\partial z}\left(K-\frac{\partial v}{\partial z}\right) \\
& \partial \pi / \partial z=g \theta / \tilde{\theta} \\
& \partial u / \partial x+\partial v / \partial y+\partial w / \partial z=0 \\
& \frac{d \theta}{d t}=-S w+K_{H}\left(\frac{\partial^{2} \theta}{\partial x^{2}}+\frac{\partial^{2} \theta}{\partial y^{2}}\right)+-\frac{\partial}{\partial z}\left(K^{-} \frac{\partial \theta}{\partial z}\right),
\end{aligned}
$$

where $d / d t=\partial / \partial t+u \partial / \partial x+v \partial / \partial y+w \partial / \partial z$, and $u, v$ and $w$ are the west-east, southnorth and vertical components of motion respectively. Here $f$ is the Coriolis parameter and $K_{H}$ is the horizontal eddy diffusion coefficient and the other notations are the same as in the two-dimensional equations.

\subsection{Conditions for numerical calculation} We use the following boundary conditions. At the surface

$$
\begin{aligned}
& u=v=w=0 \\
& \theta= \begin{cases}A \sin \left(\frac{2 \pi}{T^{-t}}\right) & \text { over land } \\
0^{\circ} & \text { over water }\end{cases}
\end{aligned}
$$

and at $1.8 \mathrm{~km}$

$$
\frac{\partial u}{\partial z}=-\frac{\partial v}{\partial z}=-\frac{\partial \theta}{\partial z}=0 \text {. }
$$

Here $A$ is the amplitude of diurnal change of potential temperature, and $T=24$ hr. In this preliminary experiment $A$ was independent of location.

As shown in the two-dimensional experiment, the magnitude of temperature perturbation rapidly decreases with height, and the vertical profile of potential temperature of the large-scale field approaches to a neutral state with increasing height (c.f. Fig. 1). Therefore vertical air motions which propagate into the upper part without damping do not yeild any significant perturbation of potential temperature, and values of horizontal advection of potential temperature are quite small. As a result perturbations of the potential temperature field in the upper part are negligibly small, and we can assume that $\pi=0$ at $1.8 \mathrm{~km}$ for integration of the equation (16).

In stead of the upper rigid boundary in the two-dimensional model, the upper part of the computation domain of this three. dimensional experiment is gently connected with an atmosphere of constant potential temperature, an autobarotropic atmosphere. Vertical motion can penetrate into the constant potential temperature layer but it does not disturb the thermal field.

The initial conditions are

$$
u=v=0 \text { and } \theta=0^{\circ} \mathrm{K} \text {. }
$$

The large scale parameters $S$ and $K$ were the same as those in the two-dimensional experiment. The horizontal diffusion coefficient $K_{H}$ was $7.5 \times 10^{2} \mathrm{~m}^{2} / \mathrm{sec}$. The value of $K_{H}$ was determined from the view point of computation smoothing rather than simulation of diffusion process.

The horizontal grid interval was $6 \mathrm{~km}$, and the computation domain was covered by $(35 \times 35)$ grid points in horizontal plan, and vertical resolution was the fifteen levels from the surface to $1.8 \mathrm{~km}$ as illustrated in 


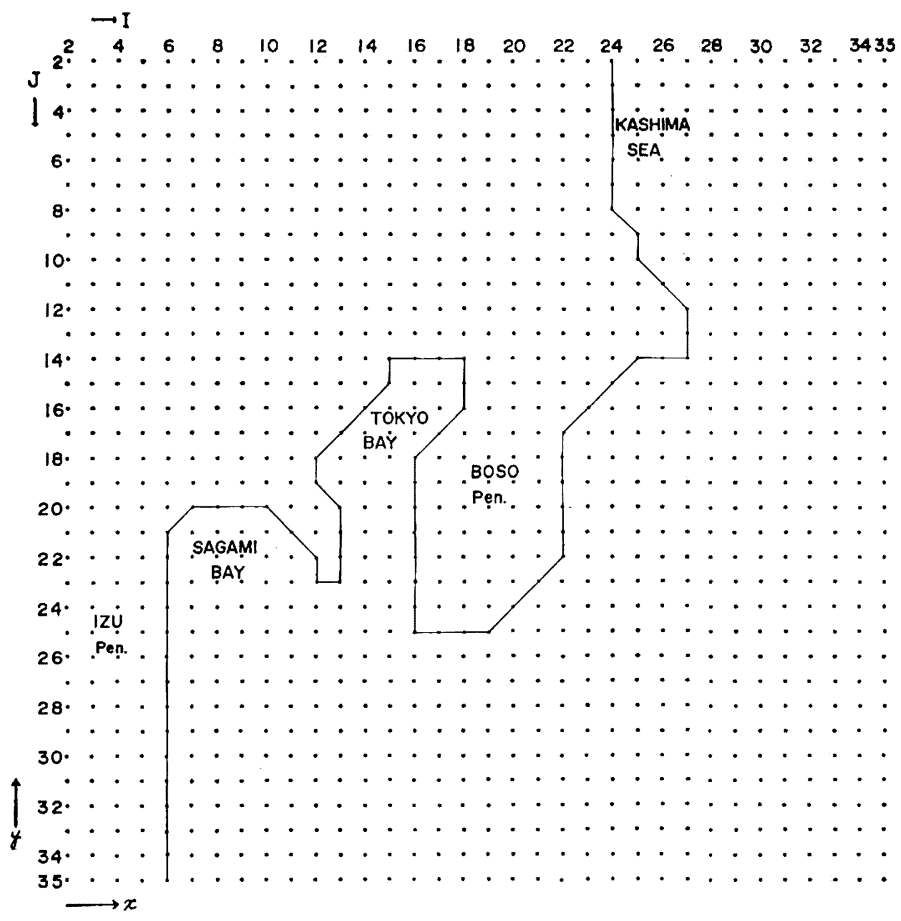

Fig. 10. Grid points and the coastline of the Kanto district of the Japanese main island. The numbers on the upper and left boundaries are the indexes for grid points.

Fig. 1. The grid mesh was superimposed on the outline of the Kanto district in Eastern Japan as shown in Fig. 10. There are long mountain ranges on the western and northern boundaries of this district. Such topography, however, was not arrowed in this experiment. At the lateral boundaries, the normal gradients of $u, v, \theta$ and $\pi$ were put to be zero.

The finite difference form of advection term was a simple flux form, and the time differencing was the Euler-backward scheme with $6 \mathrm{~min}$. time interval.

In our domain, there are two large peninsulas, Izu and Boso, and two large bays, Tokyo and Sagami. The complicated coastline causes convergence or divergence of the land and sea breezes. The land and sea breeze circulation has a great influence on the air-pollution in the large industrial area developed along Tokyo Bay.

\section{Results of the simulation of the land and sea breeze in the Kanto district}

The conditions assumed in the previous section are simpler and idealized compared with the actual physical conditions. For instance, we assumed uniform diurnal change in temperature on the land, a vertical transport coefficient which is independent of meso-scale stability, and a uniform land without river or hill. Therefore the computed land and sea breeze circulation is an idealized model of air current in the Kanto area that is expected from accepting the simplified physical conditions. Experiments were tried for three different amplitudes of diurnal temperature change: $2^{\circ}, 4^{\circ}$ and $6^{\circ} \mathrm{K}$. Time integration was carried out for $48 \mathrm{hr}$ in order to get two complete cycles of circulation and to allow for non-linear inte, action. In this paper, the result of the experiment with the diurnal amplitude of $6^{\circ} \mathrm{K}$ is presented. 


\subsection{Horizontal motion fields}

The computed horizontal motion fields at $50 \mathrm{~m}$ and $500 \mathrm{~m}$ after $24 \mathrm{hr}$, i. e., the wind fields at the second simulated dawn are shown in Figs. 11(a) and (b). At $50 \mathrm{~m}$ the land breeze prevailed over the whole domain and the wind force was strongest at the off-shore zone. This zone of strong land breeze at $12-24 \mathrm{~km}$ off-shore may be referred to as a land breeze front. The land breeze converged on the bays and diverged on the peninsulas. At $500 \mathrm{~m}$ the counter-land breeze covered the Kanto area. It should be noted that the height of $500 \mathrm{~m}$ is not always a representative height for the counter-current. The level of strong counter-current is sometimes lower than $500 \mathrm{~m}$ as shown in the vertical profiles of east-west component of wind presented in Fig. 16.

At $30 \mathrm{hr}$, i.e., $6 \mathrm{hr}$ after the second simulated sunrise, the sea breeze had appeared already along the coastal zone and made a convergence with the winds inland. On the peninsulas or the convex coastline, especially, the Bosa peninsula, the sea breeze converged and made cyclonic vortexes, while along the bay a divergence of sea breeze was found. In the flow-pattern at $500 \mathrm{~m}$ a counter-sea breeze was recognized at some places where the land and sea breeze circulation developed and reached the $500 \mathrm{~m}$-level.

At $36 \mathrm{hr}$ the sea breeze well developed, and about three convergence lines appeared in the frontal areas of sea breeze. The lines are results of internal gravity oscillation associated with the invasion of sea breeze. The wave-length of this oscillation was about $24-30 \mathrm{~km}$. This is a very shallow wave. Therefore the period estimated from the linearized governing equations is about $2.4 \mathrm{hr}$. So the phase speed is about 2.7 $\mathrm{m} / \mathrm{sec}$ and larger than the computed wind speeds. This estimated phase speed is almost the same as the propagation speed of the convergence line. The flow-pattern at $500 \mathrm{~m}$ showed the developed counter-sea breeze over the coastal area and the internal oscillation over the inland area.



Fig. 11(a). Horizontal wind directions and wind speeds on $50 \mathrm{~m}$ level at 24 hour after the first simulated sunrise. Legend for wind force is presented at right. 


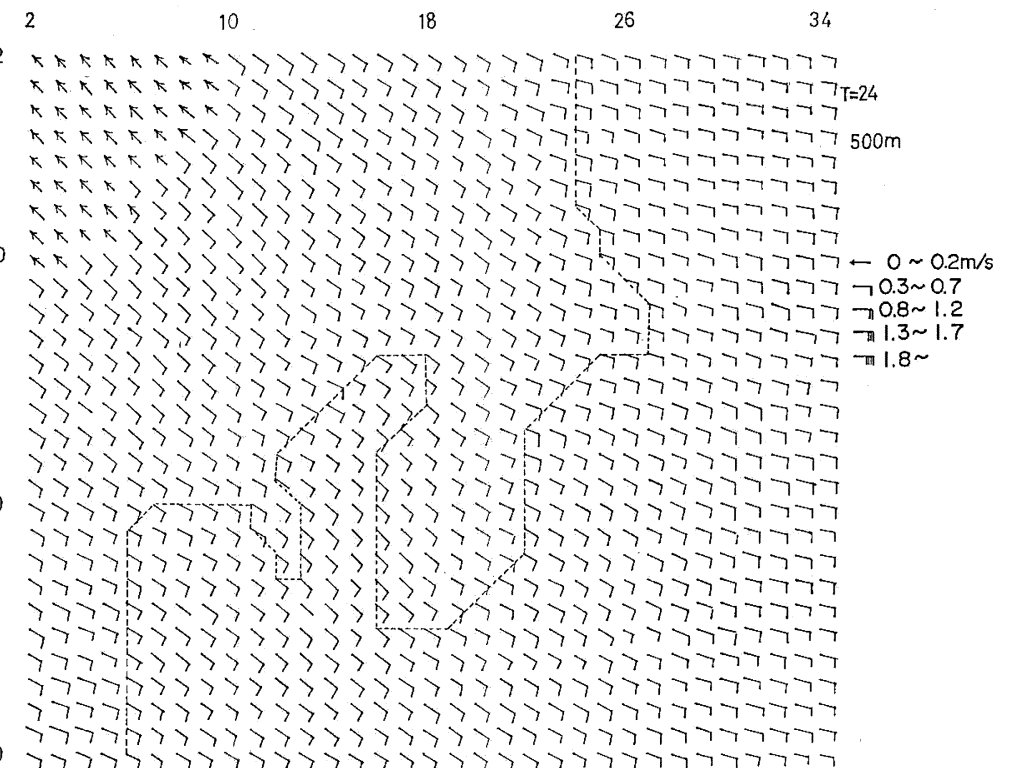

Fig. 11(b). Horizontal wind directions and wind speeds at $500 \mathrm{~m} \mathrm{level} \mathrm{at}$ 24 hour after the first simulated sunrise. Legend for wind force is presented at right.

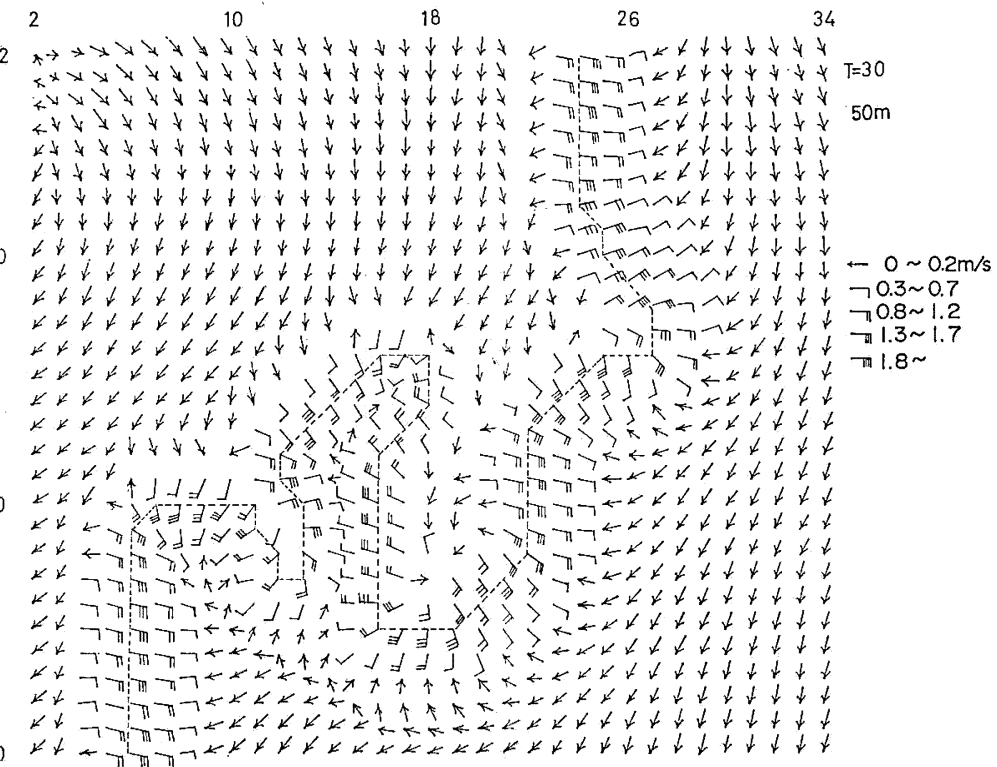

Fig. 12(a). Same as Fig. 11(a) except at 30 hour. 


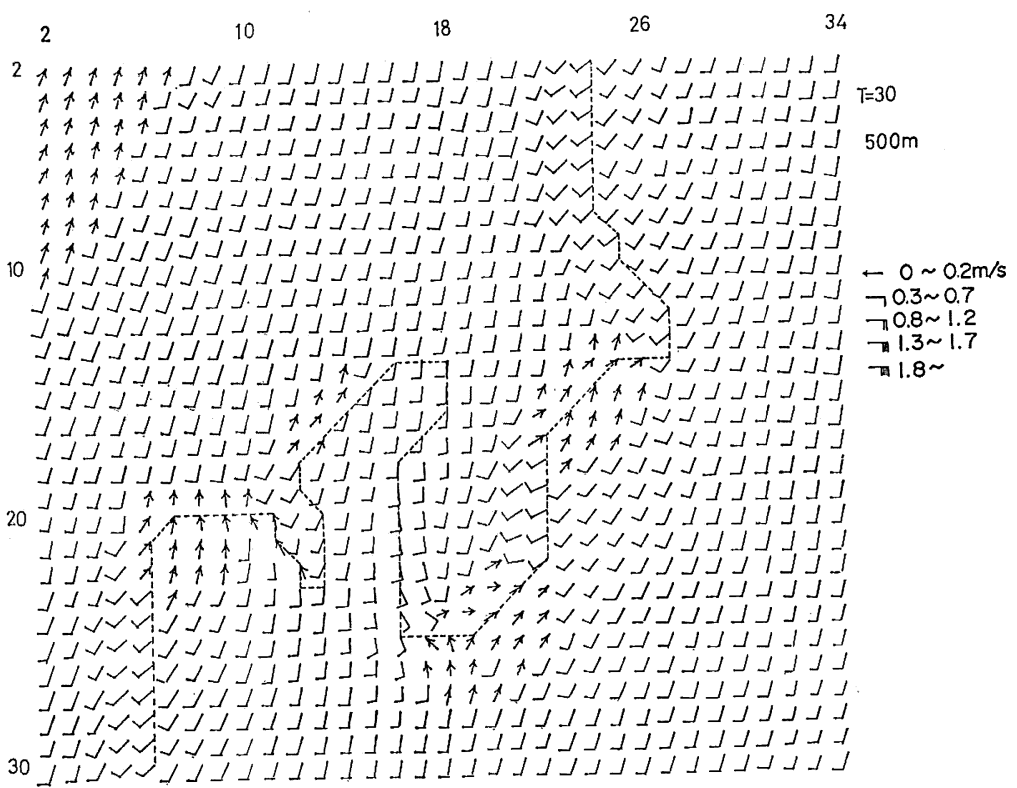

Fig. 12(b). Same as Fig. 11(b) except at 30 hour.

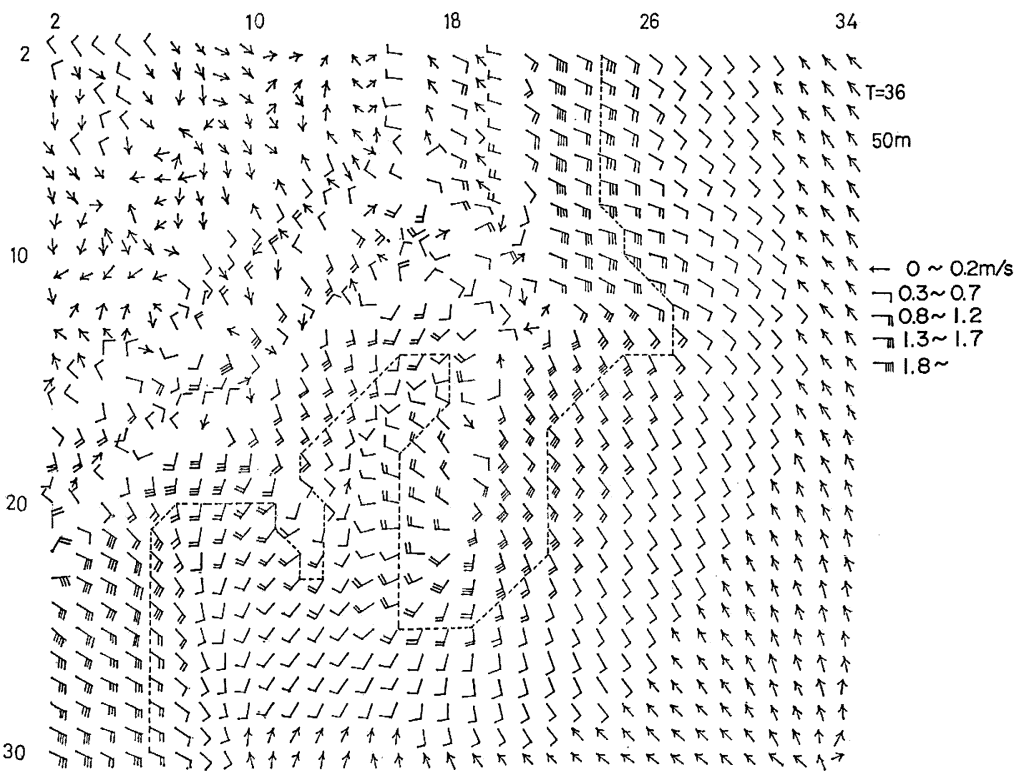

Fig. 13(a). Same as Fig. 11(b) except at 36 hour.

At $42 \mathrm{hr}$ the land breeze developed, and the maximum speed of the land breeze was found along the off-shore zone. Corresponding to the convergence zone in the day-time a remarkable divergence zone was formed on the central part of the Boso peninsula and the inland area along the Kashima coast. At $500 \mathrm{~m}$, the disturbance generated in the day-time dissolved, and relatively uniform northerly winds prevailed. The large-scale tendency in the wind fields at $500 \mathrm{~m}$ clearly showed an effect of the Coriolis force. 


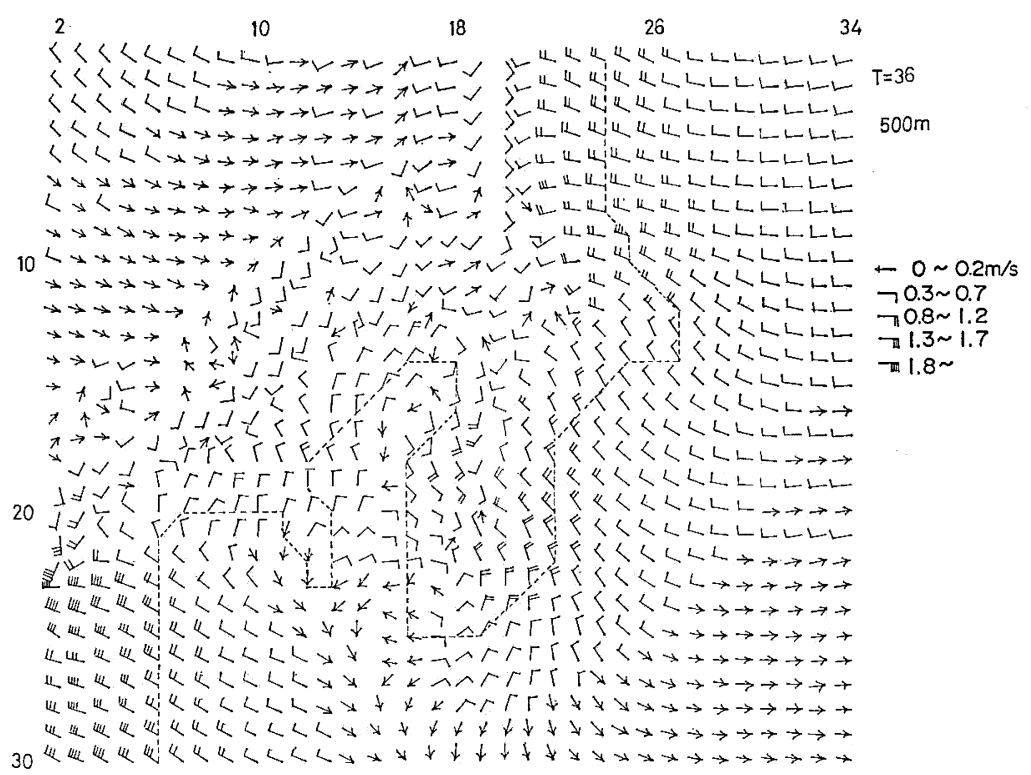

Fig. 13(b). Same as Fig. 11(b) except at 36 hour.

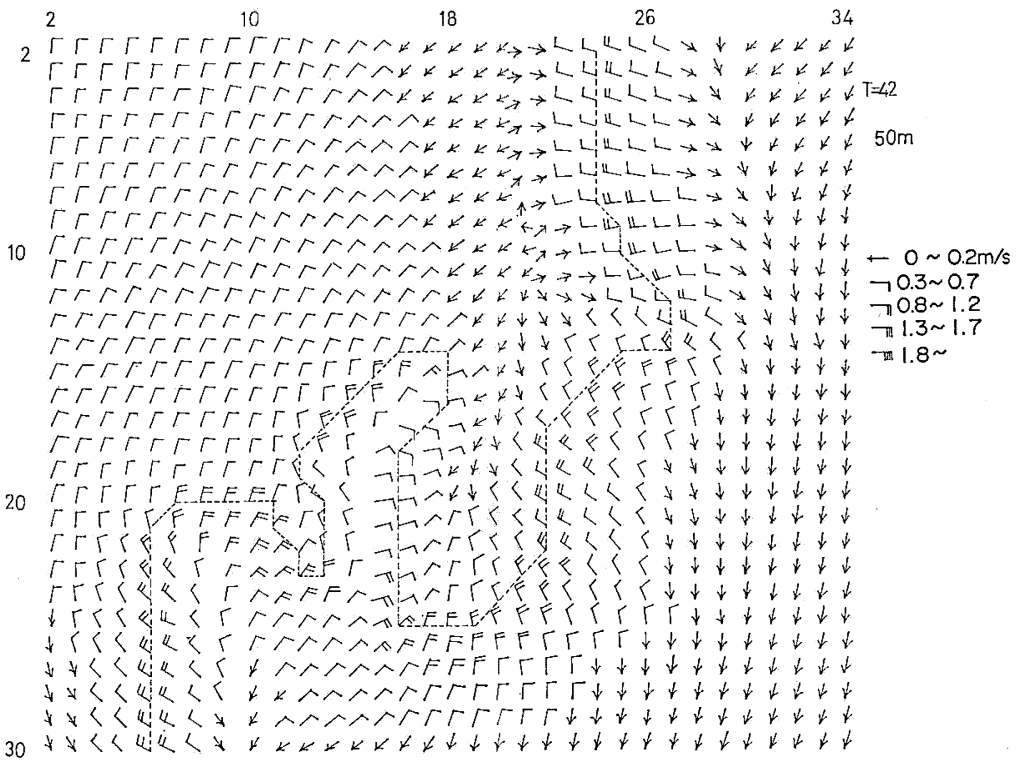

Fig. 14(a). Same as Fig. 11(a) except at 42 hour.

\subsection{Vertical motion field in $E-W$ vertical section}

The 6-hourly vertical motions in E-W vertical section during the first day are shown in Fig. 15. This vertical section is along the grid-coordinate $j=17$, which crosses
Tokyo Bay and the Boso peninsula in the west-east direction. Development, movement and alternation of the cells of upward and downward motions are found in this time sequence.

Fig. 16 shows 6 -hourly vertical profiles 


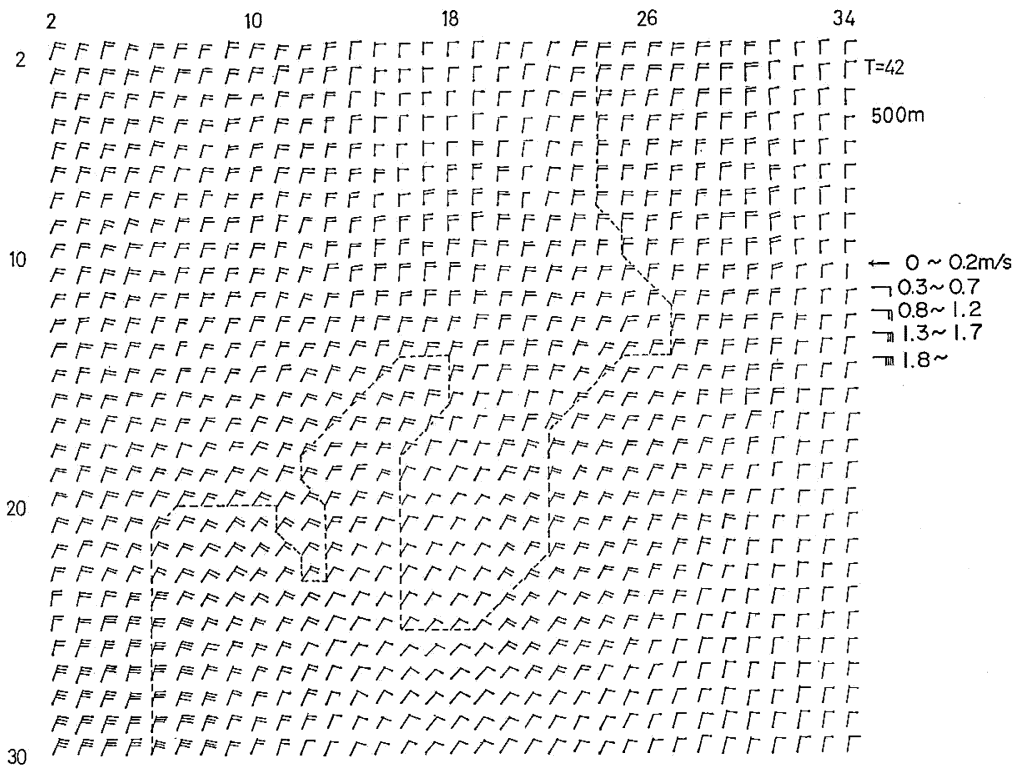

Fig. 14(b). Same as Fig. 11(b) except at 42 hour.
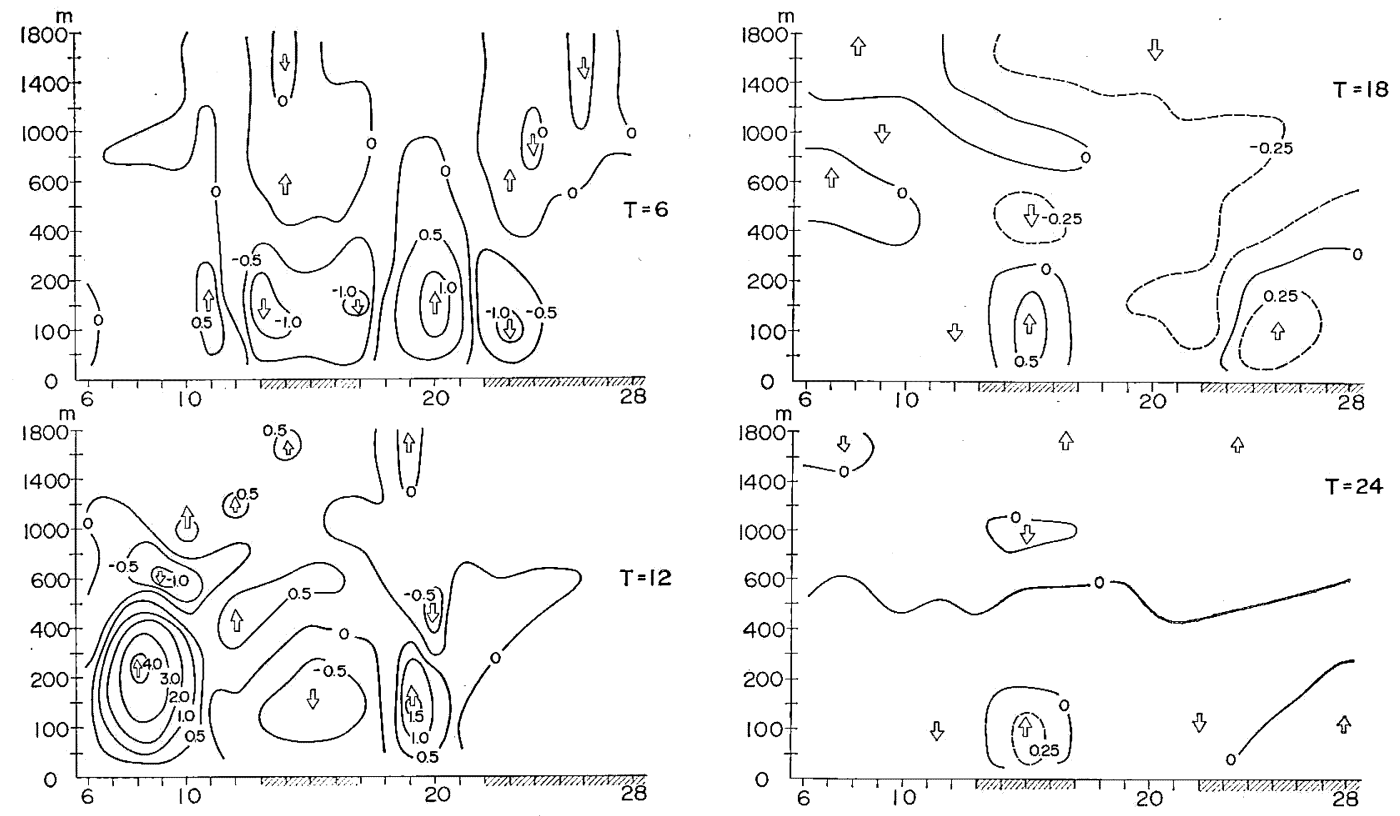

Fiǵ. 15. 6-hourly vertical motions ( $\mathrm{cm} / \mathrm{sec}$, full lines) in the vertical section along the line $j=17$. The numbers under the abscissa are the grid point index in $x$-direction and the hatched zone shows areas of water. 


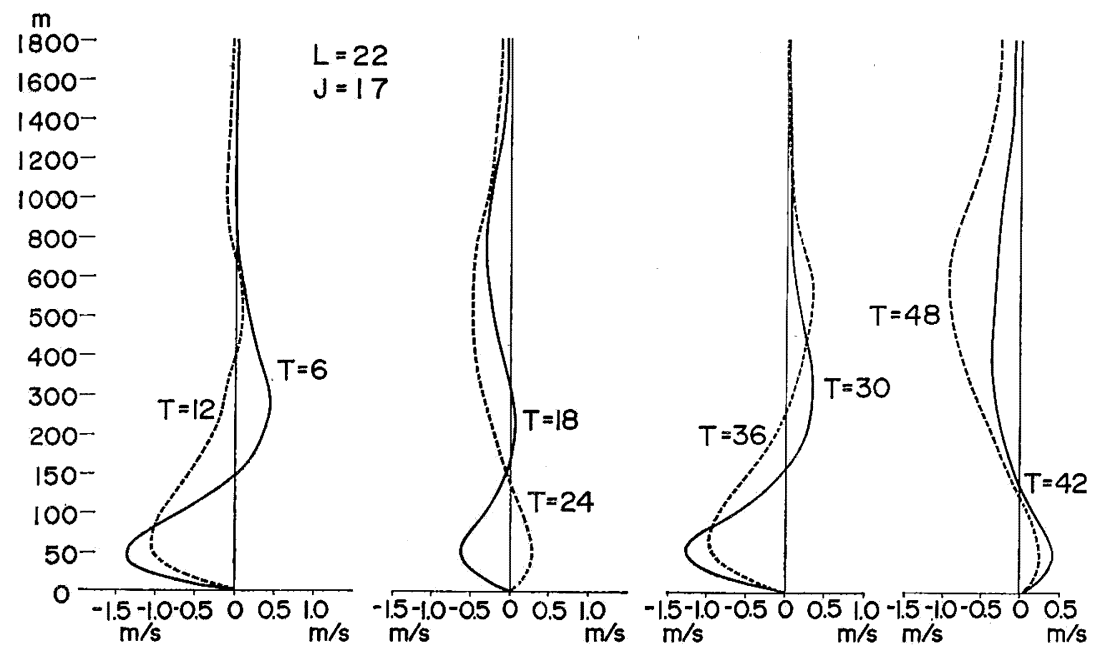

Fig. 16. 6-hourly vertical profile of the west-east component of the comput winds at the point $(i=22, j=17)$ on the coastline of the Boso peninsula.

of the west-east component of wind at a particular point on the eastern coast of the Boso peninsula. The grid-coordinates of this place are $i=22$, and $j=17$ respectively (see Fig. 10). These profiles present a detailed structure of the computed land and sea breeze circulation and its time variation.

\subsection{Turning of surface wind}

In general, the computed surface winds at the coastline turned clockwise, but there were some exceptional examples: counterclockwise turning on the eastern coast of Tokyo Bay and counter-clockwise turning of the land breeze on the coast of Sagami Bay. The direction of turning of land or sea breeze is ruled by the Coriolis force. However, convergence of sea or land breeze owing to the curvature of the coastline seems to have some effect on making the exceptional turning of the wind. This is a point that calls for further study.

Acknowledgement:- The author is in- debted to Miss K. Nishida for her valuable assistance.

\section{References}

Estoque, M. A., 1961: A theoretical study of the sea breeze. Quart. J. Royal Met. Soc., 87, 136-146.

—_ 1962: The sea breeze as a function of the prevailing synoptic situation. J. Atmos. Sci., 19, 244-250.

Estoque, M. A. and C.M. Bhumralkar, 1969: Flow over a localized heat source. Mon. Wea. Rev., 97, 850-859.

Magata, M., 1965: A study of sea breeze by the numerical experiment. Pap. Met. Geophys., 16, 23-27.

- 1972: A study of city climate by the numerical experiment. (in Japanese) TAIKI, 4, 4-15.

Neumann, J. and Y. Manrer, 1971: A theoretical study of the land sea breeze circulation. J. Atmos. Sci., 28, 532-542.

PIElKe, R., 1974: A three-dimensional numerical model of the sea breeze over South Florida. Mon. Wea. Rev., 102, 115-139. 


\title{
海陸 風 循 環 の 数 值 実 験
}

\begin{abstract}
斎 藤 直 輔
i）二次元非圧縮仮定の海陸風数值シミュレーションモデルを作り, 陸地の温度日变化が一様な場合の海陸風循 環が，海岸線に沿った都市の熱的特性によっていか炕変化するか調べた。ここでは都市は郊外より日平均気温が 高く, 日変化の振愊は郊外より小さいとしてある。計算は水平間隔が $6 \mathrm{~km}$, 高さ $1.8 \mathrm{~km}$ までを 15 のレベルに分 解した大きさ $(35 \times 15)$ の格子を用いた。前記の条件下では都市の存在は海風の内陸部への侵入を拉くらせ, 夜間 の陸風を強化する。海岸線の近くと, 都市と郊外の境界に収束場ができて, 都市のない場合の単一の鉛直循環は二 つの循環細胞に分れる。日中は都市の上空 $200 \mathrm{~m}$ 付近に発散場, 夜間は都市の海岸寄りの部分の上空に収束, 都市 の郊外寄りの上空に発散が出来る。

ii）二次元モデルを三次元に拡張し，関東地方を大きさ $35 \times 35 \times 15$ の格子 (水平間隔は同じく $6 \mathrm{~km}$ ) で怙括い, 海岸線を近似して三次元の海陸風循環の数值シミュレーションを試みた。ここでは陸地の温度の日变化の振幅は一 様とし, 山脈や川河はなく陸地は一様と仮定した。積分は 2 日分行なった。海陸風の交替, 海岸線の曲率に対応し た陸風，又は海風の収束，発散，特に房総半島の海風の収束による渦の形成，海風前線，陸風前線の形成，海風前 線の内陸侵入に伴う内部重力波の発生等の結果を得た。本文では陸地の温位の日変化の振愊を $6^{\circ} \mathrm{K}$ とした場合の 結果を示す。この場合, 海岸線での海風の極大は $1.5 \mathrm{~m} / \mathrm{s}$, 厚さは $400 \mathrm{~m}$ に達し, その上に極大 $0.5 \mathrm{~m} / \mathrm{s}$, 厚さ $725 \mathrm{~m}$ の反流がみられた。夜間は海岸線上で陸風の最大は $0.5 \mathrm{~m} / \mathrm{s}$, 厚さ $125 \mathrm{~m}$, 陸風の極大は沖合 $20 \mathrm{~km}$ 前後に みられた。
\end{abstract}

